\title{
BIOSYNTHESIS OF THE GLYCOCINNAMOYLSPERMIDINE ANTIBIOTIC, CINODINE
}

\author{
S. H. L. Chiu* ${ }^{*}$, R. Fiala, R. Kennett, \\ L. WOZNIAK and M. W. BULLOCK* \\ Agricultural Research Division, American Cyanamid Company \\ Princeton, New Jersey 08540, U.S.A.
}

(Received for publication April 25, 1983)

\begin{abstract}
The biosynthesis of cinodine from a combination of ${ }^{14} \mathrm{C}$ - and ${ }^{13} \mathrm{C}$-labeled precursors has been investigated. Tyrosine was shown to be incorporated efficiently into the cinnamoyl moiety and glucosamine was found to be the origin of the three carbohydrate moieties. The relationship between the substrate dose and the enrichment of the labeled antibiotic has been elucidated so that it is possible to predict both the specific activity and the yield of the antibiotic obtained from the labeled substrates.
\end{abstract}

Cinodine, the broad-spectrum antibiotic formerly called LL-BM123 $\beta, \gamma_{1}$ and $\gamma_{2}$ was isolated and identified at Lederle Laboratories ${ }^{1,2)}$. The $\gamma_{1}$ and $\gamma_{2}$ components have broad-spectrum activity against Gram-negative organisms and a protective effect against infections in mice ${ }^{3)}$. Cinodine has been found effective in controlling shipping fever in cattle ${ }^{4)}$. The compound is a glycocinnamoylspermidine, structurally consisting of a trisaccharide, a cinnamic acid and spermidine (Fig. 1). Chemically, cinodine exhibits instability at strong acidic and basic conditions $\mathrm{s}^{5)}$. Degradation was observed in acidic $\mathrm{pH}$, and conversion of the $\gamma$ components to the biologically less active $\beta$ component took place readily at basic conditions. It this paper, we report on the incorporation of ${ }^{14} \mathrm{C}$-labeled precursors into the trisaccharide and the cinnamoyl moieties as well as implications on the biosynthetic pathway of the antibiotic.

Fig. 1. Structure of cinodine.

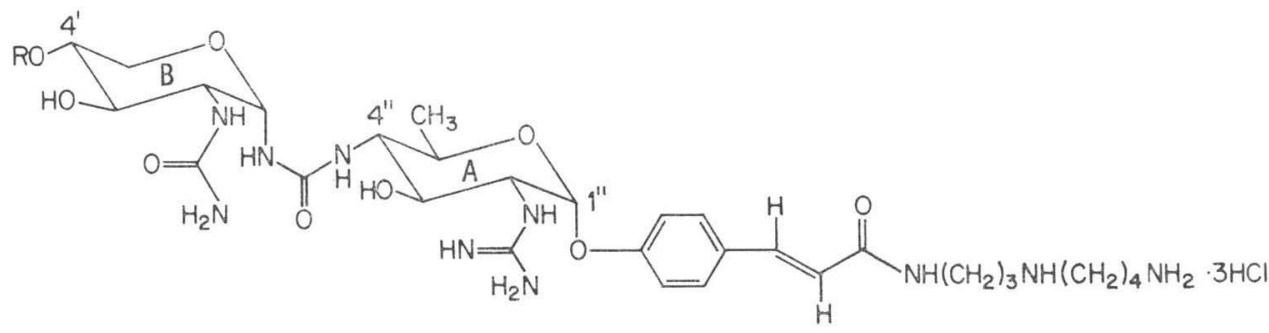

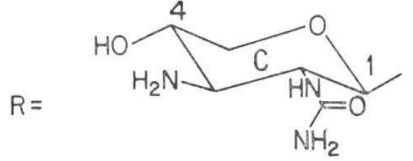

$\beta$

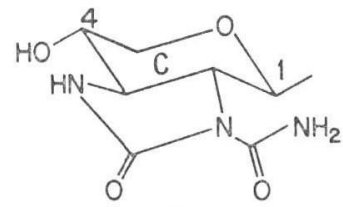

$\gamma_{1}$

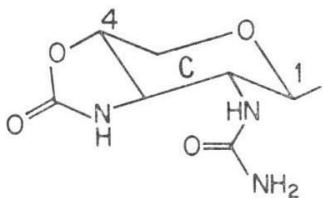

$\gamma_{2}$

† Current address: Merck Sharp \& Dohme Research Laboratories, P.O. Box 2000, Rahway, NJ 07065, U.S.A. 


\section{Materials and Methods}

Strains

Nocardia sp. strains LK-2558, LK-1034 and KL-5228, maintained on agar slants, were obtained from Lederle Laboratories.

Chemicals

$\mathrm{L}-\left[U_{-}{ }^{14} \mathrm{C}\right]$ Tyrosine $(256 \mathrm{mCi} / \mathrm{mmol}$, Amersham Co. $) ; \mathrm{D}-\left[U_{-}{ }^{14} \mathrm{C}\right]$ glucosamine $(310 \mathrm{mCi} / \mathrm{mmol}, \mathrm{New}$ England Nuclear Co.); DL- $\left[2-{ }^{13} \mathrm{C}\right]-p$-hydroxyphenylalanine (tyrosine, E. Merck \& Co.) were purchased. $\mathrm{D}-\left[1-{ }^{13} \mathrm{C}\right]$ Glucosamine was prepared in our laboratory by a published method ${ }^{6)}$ with modifications in that $\left[{ }^{13} \mathrm{C}\right] \mathrm{KCN}\left(90 \%\right.$ atom ${ }^{13} \mathrm{C}$, E. Merck Co.) was used. The recrystallized compound had $\mathrm{mp} 189 \sim$ $192^{\circ} \mathrm{C}(\mathrm{dec}),[\alpha]_{\mathrm{D}}+84.5^{\circ}\left(c 0.985, \mathrm{H}_{2} \mathrm{O}\right)$.

Fermentation

After $8 \sim 10$ days growth on slants at $28 \sim 30^{\circ} \mathrm{C}$, the mature cultures were washed from the slants into $5 \sim 10 \mathrm{ml}$ sterile $\mathrm{H}_{2} \mathrm{O}$. One milliliter of this suspension was used to inoculate $25 \mathrm{ml}$ of medium consisting of Hormel meat solubles 15, Cerulose 20, $\left(\mathrm{NH}_{4}\right)_{2} \mathrm{SO}_{4} 3, \mathrm{~K}_{2} \mathrm{HPO}_{4} 3, \mathrm{MgSO}_{4} \cdot 7 \mathrm{H}_{2} \mathrm{O} 1.5$, Bacto-Peptone 10 and $\mathrm{CaCO}_{3} 2 \mathrm{~g} /$ liter in a $250-\mathrm{ml}$ flask. After shaking for $2 \sim 3$ days at $28^{\circ} \mathrm{C}, 1 \mathrm{ml}$ of this seed culture was used to inoculate $25 \mathrm{ml}$ of production medium identical to the above except that glucose and meat solubles were increased to 80 and $60 \mathrm{~g} /$ liter, respectively. The fermentations were allowed to proceed $7 \sim 10$ days on a rotary shaker at $25^{\circ} \mathrm{C}$. Additions of isotopically-labeled precursors were carried out at various time points by removing a flask from the shaker into a controlled environment class 100 laboratory. To harvest the culture, contents of each flask were quantitatively transferred and centrifuged at $4,000 \times g$ for 5 minutes. The supernatant was re-centrifuged at $15,000 \times g$ for 10 minutes. Measurements of antibiotic concentration and radioactivity were carried out on the final supernatant samples. In every fermentation, two flasks were used as controls and each parameter was evaluated in duplicate flasks.

\section{Dose of Radioactive Precursor}

For the convenience of comparing the relative efficiency of incorporation of radiolabeled precursors on an equimolar basis, the compounds were added with unlabeled carriers usually at fractions or multiples of the total $\mu \mathrm{mol}$ of cinodine produced. Total radioactivity added to each $25 \mathrm{ml}$ medium was between $8 \sim 11 \mu \mathrm{Ci}$.

Isolation and Analysis of Antibiotic

Reversed-phase high-performance liquid chromatography (HPLC) was used to isolate the antibiotic from the fermentation broth as well as analysis of its concentration. A liquid chromatograph (Micromeritics, Model 7000) equipped with a variable wavelength detector (Micromeritics, Chromonitor 785 ) and a recorder-integrator (Hewlett-Packard 3380A) was used in the analyses. Chromatograms were monitored at $280 \mathrm{~nm}$. A $\mu$ Bondapak C-18 column (Waters Assoc. $3.9 \mathrm{~mm} \times 30 \mathrm{~cm}$ ) was used with the following solvent systems: (A) $\mathrm{MeOH}-\mathrm{H}_{2} \mathrm{O}-\mathrm{AcOH}(84: 15: 1), 0.05 \mathrm{M}$ in sodium acetate and (B) $\mathrm{MeOH}-\mathrm{H}_{2} \mathrm{O}-\mathrm{AcOH}(50: 49: 1), 0.005 \mathrm{M}$ in sodium heptane sulfonate. A standard solution of cinodine at $100 \mu \mathrm{g} / \mathrm{ml}$ was used as external standards in all assays. Antibiotic concentrations in some cases were checked by microbiological assays using the agar-diffusion method.

Isolation of cinodine in a preparative experiment was done by pooling fermentation broths, filtering through Celite and chromatographing on a CM-Sephadex ion-exchange column which was eluted with a $1 \sim 5 \%$ sodium chloride gradient. The column effluent fractions containing the desired components were desalted with a UM-05 membrane filter (Amicon Co.) and lyophilized.

Radioanalysis

Radioactivity in the HPLC effluent fractions was measured by liquid scintillation counting using the external standardization method.

Nuclear Magnetic Resonance Spectroscopy (NMR)

Proton-decoupled ${ }^{13} \mathrm{C}$ NMR spectra were recorded with a Varian FT-80A NMR spectrometer with broad band probe at $20 \mathrm{MHz}$. Tetramethylsilane (TMS) was used as external standard in all 
Table 1. Effect of time of addition of $\left[{ }^{14} \mathrm{C}\right]$ tyrosine on incorporation into cinodine ${ }^{\mathrm{a}}$.

\begin{tabular}{|c|c|c|c|c|c|}
\hline \multirow{2}{*}{$\begin{array}{c}\text { Day } \\
{ }^{14} \mathrm{C} \text { added }\end{array}$} & \multirow{2}{*}{$\begin{array}{c}\text { Day } \\
\text { culture } \\
\text { harvested }\end{array}$} & \multicolumn{2}{|c|}{$\beta+\gamma_{1}+\gamma_{2}$} & \multicolumn{2}{|c|}{$\gamma_{1}+r_{2}$} \\
\hline & & $\begin{array}{l}\text { Specific activity } \\
(\mu \mathrm{Ci} / \mathrm{mg})\end{array}$ & $\begin{array}{c}\text { Incorporation } \\
(\%)\end{array}$ & $\begin{array}{l}\text { Specific activity } \\
(\mu \mathrm{Ci} / \mathrm{mg})\end{array}$ & $\begin{array}{c}\text { Incorporation } \\
(\%)\end{array}$ \\
\hline \multirow[t]{2}{*}{3} & 4 & 0.048 & 10.6 & 0.052 & 9.4 \\
\hline & & 0.051 & 10.8 & 0.055 & 9.3 \\
\hline \multirow[t]{2}{*}{4} & 5 & 0.022 & 5.8 & 0.017 & 3.4 \\
\hline & & 0.026 & 6.6 & 0.024 & 4.5 \\
\hline \multirow[t]{2}{*}{5} & 6 & 0.020 & 5.8 & 0.019 & 2.7 \\
\hline & & 0.023 & 6.7 & 0.010 & 2.0 \\
\hline
\end{tabular}

a Amount added to each $25 \mathrm{ml}$ medium was $9.8 \mu \mathrm{Ci} / 1.57 \mathrm{mg}$.

Table 2. Effect of duration of $\left[{ }^{14} \mathrm{C}\right]$ tyrosine addition on incorporation into cinodine ${ }^{\mathrm{a}}$.

\begin{tabular}{ccccccc}
\hline \multirow{2}{*}{$\begin{array}{c}\text { Day } \\
{ }^{14} \mathrm{C} \text { added }\end{array}$} & $\begin{array}{c}\text { Day } \\
\text { culture } \\
\text { harvested }\end{array}$ & $\begin{array}{c}\text { Specific activity } \\
(\mu \mathrm{Ci} / \mathrm{mg})\end{array}$ & $\begin{array}{c}\text { Incorporation } \\
(\%)\end{array}$ & & $\begin{array}{c}\text { Specific activity } \\
(\mu \mathrm{Ci} / \mathrm{mg})\end{array}$ & $\begin{array}{c}\text { Incorporation } \\
(\%)\end{array}$ \\
\hline 3 & 4 & 0.050 & 10.7 & & 0.054 & 9.4 \\
3 & 5 & 0.049 & 13.1 & & 0.051 & 10.1 \\
3 & 6 & 0.045 & 13.5 & & 0.048 & 9.4 \\
3 & 7 & 0.038 & 13.1 & & 0.039 & 8.6 \\
\hline
\end{tabular}

a Amount added same as Table 1.

samples. Enrichment of peaks was estimated by integration of peak areas.

\section{Results and Discussion}

Preliminary studies with L-tyrosine, L-phenylalanine and $p$-coumaric acid showed that all three were efficiently incorporated into cinodine. The efficiencies of $p$-coumaric acid and L-tyrosine incorporation were about equal and slightly better than L-phenylalanine when compared at equimolar concentrations. We selected to use L-tyrosine for further studies because a supply of highly radioactive material was conveniently available. The best time for precursor addition was found to be at the onset of significant antibiotic production, i.e., during the third day of the fermentation. The profile of Ltyrosine incorporation at different addition times is summarized in Table 1. Results shown in Table 2 indicate that the incorporation of L-tyrosine was essentially complete in 2 days when the precursor was added on the third day post inoculation. The effect of increasing the amount of L-tyrosine added on the incorporation efficiency and product specific activity is summarized in Table 3 . The steep decrease in the incorporation efficiency with the increase of L-tyrosine from $0.7 \mathrm{mg}$ to $4.66 \mathrm{mg} / \mathrm{flask}$ suggests that the L-tyrosine content of the medium was so small that dilution was readily reflected in the incorporation (Fig. 2).

In order to locate the labeled carbons in the antibiotic produced from $\mathrm{L}-\left[U-{ }^{14} \mathrm{C}\right]$ tyrosine, a preparative experiment in a 2-liter stirred fermenter was done with a mixture of $97 \mathrm{mg}$ DL-[2- $\left.{ }^{13} \mathrm{C}\right]$ tyrosine and $55.8 \mu \mathrm{Ci}(0.02 \mathrm{mg}) \mathrm{L}-\left[U-{ }^{14} \mathrm{C}\right]$ tyrosine. The purified cinodine obtained had a specific activity of $0.0038 \mu \mathrm{Ci} / \mathrm{mg}$. Since the total amount of antibiotic produced was found to be $1,311 \mathrm{mg}$, the total ${ }^{14} \mathrm{C}$ incorporation was $5 \mu \mathrm{Ci}$ or $8.9 \%$. The $\left[{ }^{13} \mathrm{C}\right]$ tyrosine that was used in the fermentation was a $\mathrm{D}, \mathrm{L}$ mixture and it could be assumed that only the L-isomer was used by the microorganism. Therefore, 
Table 3. Effect of dosage of $\left[{ }^{14} \mathrm{C}\right]$ tyrosine on incorporation into cinodine ${ }^{a}$.

\begin{tabular}{ccccc}
\hline \multicolumn{2}{c}{ L-Tyrosine } & & $\begin{array}{c}{ }^{14} \mathrm{C} \\
\text { incorpora- } \\
\text { tion } \\
(\%)\end{array}$ & $\begin{array}{c}\text { Specific } \\
\text { activity } \\
(\mu \mathrm{Ci} / \mathrm{mg})\end{array}$ \\
\cline { 1 - 2 } $\mathrm{mg}$ & $\mu \mathrm{Ci}$ & 19.8 & 16.4 \\
1.66 & 2,000 & 16.2 & 0.052 \\
2.32 & 8.82 & 16.2 & 0.051 \\
& & 8.82 & 11.5 & 0.039 \\
4.66 & 8.82 & 7.9 & 0.037 \\
& & 8.8 & 0.027 \\
\hline
\end{tabular}

a Added on 4th day to $25 \mathrm{ml}$ medium. Harvested on 10 th day.

Table 4. Effect of dosage of $\mathrm{D}-\left[U_{-}{ }^{14} \mathrm{C}\right]$ glucosamine $\mathrm{HCl}$ on incorporation into cinodine ${ }^{\mathrm{a}}$.

\begin{tabular}{|c|c|c|c|c|}
\hline \multicolumn{3}{|c|}{$\mathrm{D}-\left[U-{ }^{14} \mathrm{C}\right]$ Glucosamine } & \multirow{2}{*}{$\begin{array}{c}\text { Incorpora- } \\
\text { tion } \\
(\%)\end{array}$} & \multirow{2}{*}{$\begin{array}{l}\text { Specific } \\
\text { activity } \\
(\mu \mathrm{Ci} / \mathrm{mg}\end{array}$} \\
\hline $\mathrm{mg} / \mathrm{flask}$ & $\begin{array}{l}\mu \mathrm{Ci} / \\
\text { flask }\end{array}$ & $\begin{array}{c}\text { Day } \\
\text { added }\end{array}$ & & \\
\hline \multirow[t]{2}{*}{1.39} & 11.2 & 3 & 8.11 & 0.039 \\
\hline & & & 7.37 & 0.038 \\
\hline \multirow[t]{2}{*}{2.78} & 11.2 & 3 & 6.02 & 0.030 \\
\hline & & & 6.34 & 0.031 \\
\hline \multirow[t]{2}{*}{5.55} & 11.2 & 3 & 4.72 & 0.024 \\
\hline & & & 5.17 & 0.026 \\
\hline \multirow[t]{2}{*}{1.39} & 11.2 & 4 & 6.78 & 0.035 \\
\hline & & & 7.12 & 0.038 \\
\hline $2 \times 1.39$ & $2 \times 11.2$ & 3,4 & 4.21 & 0.041 \\
\hline
\end{tabular}
tion.
Fig. 2. Relationship of $\left[{ }^{14} \mathrm{C}\right]$ tyrosine and $\left[U-{ }^{14} \mathrm{C}\right]-$ glucosamine $\cdot \mathrm{HCl}$ doses to incorporation efficiencies into cinodine.

Substrates were added to $25 \mathrm{ml}$ medium either on the third $\left(\left[U_{-}{ }^{14} \mathrm{C}\right]\right.$ glucosamine $\left.\cdot \mathrm{HCl}\right)$ or the 4 th day $\left(\left[{ }^{14} \mathrm{C}\right]\right.$ tyrosine $)$ after inoculation and harvested on the 10th day. Doses of $\left[{ }^{14} \mathrm{C}\right]$ tyrosine (๑) were $0.7,1.66,2.32$ and $4.66 \mathrm{mg}$ and $\left[U-{ }^{14} \mathrm{C}\right]-$ glucosamine $\cdot \mathrm{HCl}(\bigcirc) 1.39,2.78$ and $5.55 \mathrm{mg}$ as described in Tables 3 and 4.

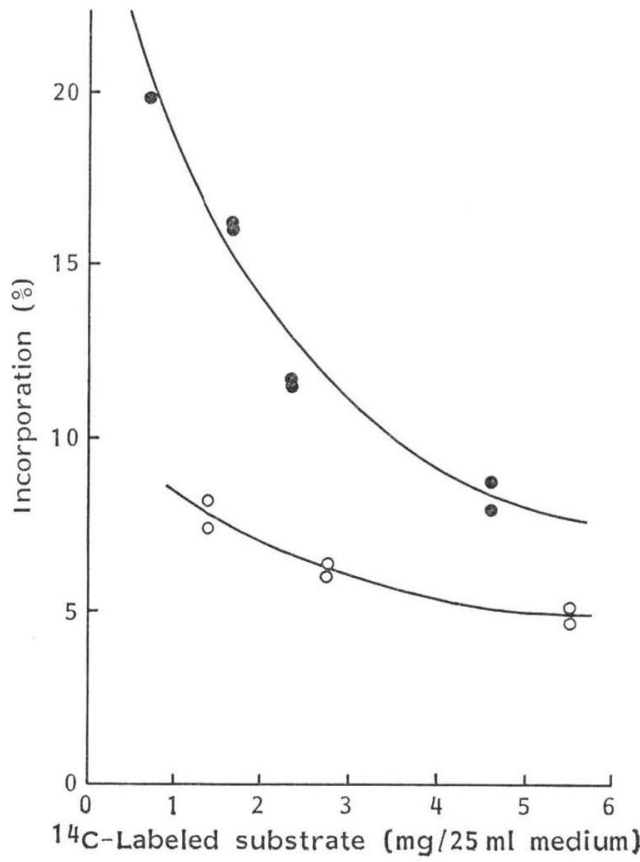

of the $97 \mathrm{mg}$ of $\left[{ }^{13} \mathrm{C}\right]$ tyrosine supplied, $48.5 \mathrm{mg}$ of the L-isomer were actually available to the culture and $8.9 \%$ of this amount $(4.3 \mathrm{mg})$ was incorporated into the antibiotic as calculated based on ${ }^{14} \mathrm{C}$ incorporation. Taking into consideration that the precursor was $90 \%$ atom ${ }^{13} \mathrm{C}$ and assuming that the ${ }^{13} \mathrm{C}$ enriched carbon-2 atom reappears only in the carbon- 2 of the cinnamoyl moiety, then an enrichment was calculated to be 2.47 -fold over natural abundance, which was $2.74 \%{ }^{13} \mathrm{C}$ atom at the carbon-2 position.

The proton decoupled ${ }^{13} \mathrm{C}$ NMR spectrum (Fig. 3) was compared to the reference spectrum of cinodine obtained under identical conditions. At $124 \mathrm{ppm}$, an enhanced signal was present which, according to the peak assignment ${ }^{4}$ in the structure determination of cinodine, was the $\beta$ carbon of the cinnamoyl moiety, the same atom (carbon-2) of the tyrosine precursor. This signal measured 2.55 -fold enrichment over natural abundance $(1.11 \%)$, corresponding to $2.83 \%{ }^{13} \mathrm{C}$ atom. The close agreement of the enrichment confirmed that tyrosine was, indeed, only being incorporated in the cinnamoyl moiety in the cinodine molecule and that the tyrosine incorporated with the 3-carbon side chain intact. It also confirmed the assumption that only the L-isomer of tyrosine was the precursor of cinodine.

Biosynthesis of the carbohydrate moiety in cinodine is more difficult to predict because of the 
Fig. 3. ${ }^{13} \mathrm{C}$ NMR spectrum of cinodine $\left(\gamma_{2}\right)$ labeled with DL- $\left[2-{ }^{13} \mathrm{C}\right]$ tyrosine.

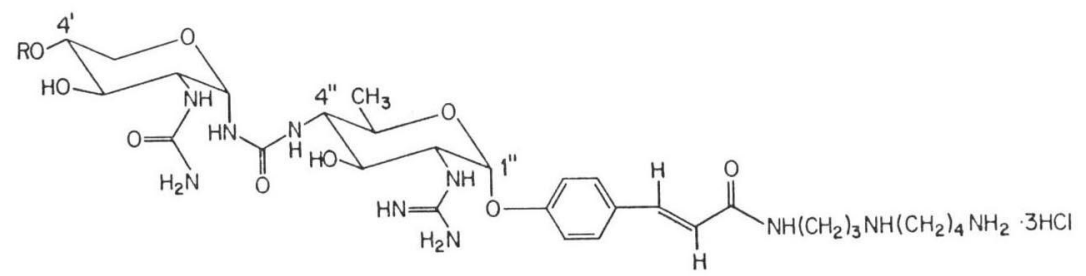

$R=$

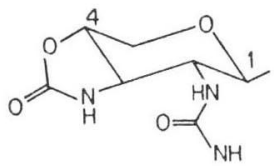

$\gamma_{2}$

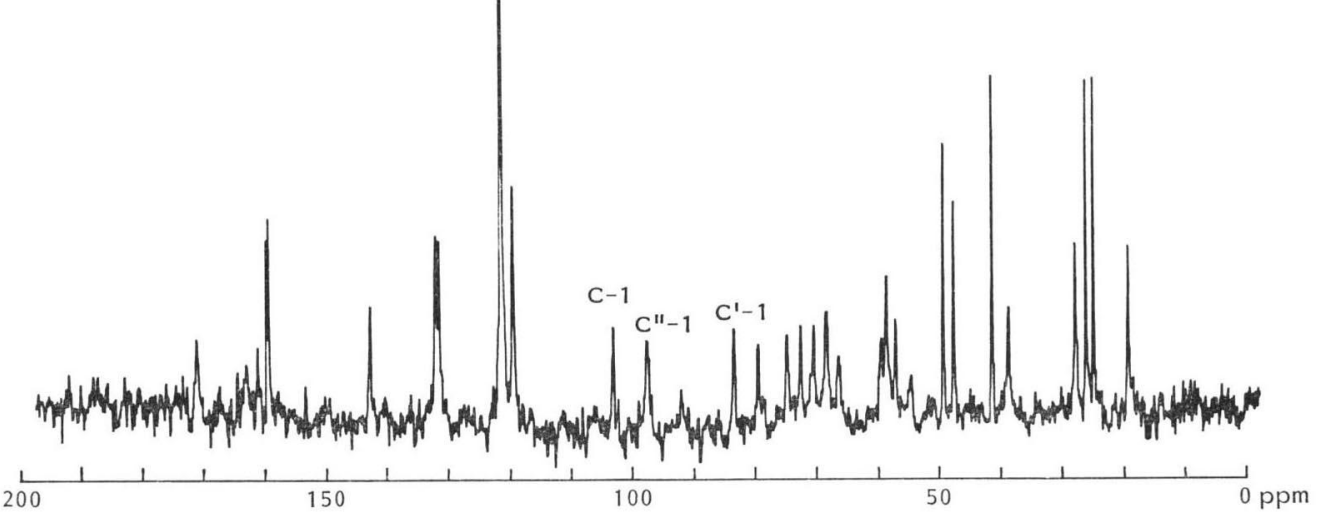

more complicated metabolic pathways of sugars, although their origin can probably be traced to glucose. Since the fermentation medium contained an abundant supply of glucose as the energy source, extensive isotope dilution and low incorporation efficiency would be predicted if radiolabeled glucose is used as precursor. A preliminary study has shown that it was incorporated at less than $1 \%$. Since all the sugar moieties in the molecule bear an amino function at carbon-2, D-glucosamine was suspected to be an intermediate in their biosyntheses.

The profile of D-glucosamine incorporation was studied with ${ }^{14} \mathrm{C}$ labeled precursor. The results in Table 4 indicate that increasing the amount of glucosamine resulted in a less steep decline of incorporation efficiencies of cinodine compared with that in the tyrosine incorporation (Fig. 2). At a relatively high loading dose of $1 \mu \mathrm{mol}$ of substrate $(5.55 \mathrm{mg} /$ flask), reasonable incorporation could be obtained which is most desirable in preparative experiments.

The synthetic $\mathrm{D}-\left[1-{ }^{13} \mathrm{C}\right]$ glucosamine was added to the fermentation culture on the third day with a trace amount of $\mathrm{D}-\left[1-{ }^{14} \mathrm{C}\right]$ glucosamine $\cdot \mathrm{HCl}$ for the same purpose as in the tyrosine study. Results obtained in this fermentation showed that $21.2 \%$ of ${ }^{14} \mathrm{C}$ radioactivity was incorporated into $1.61 \mathrm{~g}(1.606$ $\mathrm{mmol})$ of cinodine, which corresponded to $42.4 \mathrm{mg}(0.197 \mathrm{mmol})$ of the $\left[{ }^{13} \mathrm{C}\right] \mathrm{glucosamine}$ being incorporated in the product. Therefore, the percentage of ${ }^{13} \mathrm{C}$ moiety in cinodine should be 12.3 , or 11.1 atom percent when calculated at 90 atom percent of ${ }^{13} \mathrm{C}$ in the tracer. Therefore, a total of 11 -fold ${ }^{13} \mathrm{C}$ enrichment should be observed if the label appeared only in one position. If the label was found uniformly distributed in all three monosaccharide moieties, then each ring should have $3.7 \%{ }^{13} \mathrm{C}$ above 
Fig. 4. ${ }^{13} \mathrm{C}$ NMR spectrum of cinodine $(\beta)$ labeled with $\mathrm{D}-\left[1-{ }^{13} \mathrm{C}\right]$ glucosamine $\cdot \mathrm{HCl}$.

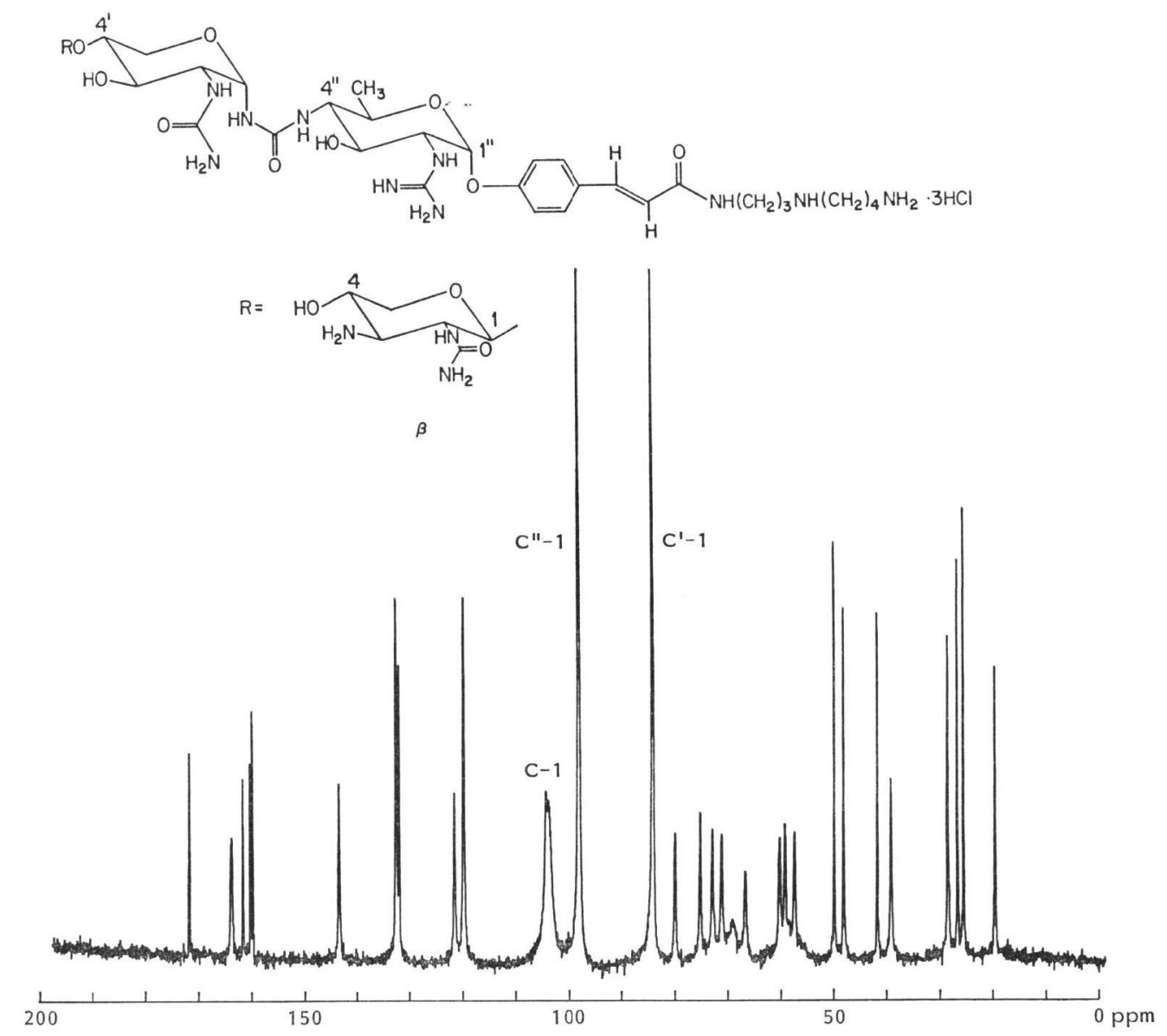

natural abundance.

The ${ }^{13} \mathrm{C}$ NMR spectra of glucosamine incorporated cinodine showed that all three anomeric carbons, $\mathrm{C}^{\prime \prime}-1$ (ring A), $\mathrm{C}^{\prime}-1$ (ring B) and C-1 (ring C) of the molecule were enriched. In the spectrum of the $\beta$ component (Fig. 4), the anomeric carbons $C^{\prime}-1, C^{\prime \prime}-1$ and $C-1$ were shown to have chemical shifts of $83.66,97.58$ and $103.5 \mathrm{ppm}$ vs. external standard (TMS). (The assignments of these carbons by ELLESTAD et al. were 82.45, 96.0 and $103.2 \mathrm{ppm}$ with dioxane as the internal standard.) The enrichment was estimated to be $C^{\prime \prime}-1$ (ring A) 7.4, C'-1 (ring B) 6.4 and C-1 (ring C) 5.2, a total of 19.0fold enrichment. The spectrum of the $\gamma$ sample which consisted of $25 \%$ of $\gamma_{1}$ and $75 \%$ of $\gamma_{2}$, showed that signals for $C^{\prime}-1$ from both $\gamma_{1}$ and $\gamma_{2}$ were overlapping at $83.74 \mathrm{ppm}$ and $\mathrm{C}^{\prime \prime}-1$ of both components appeared as one single peak at $97.79 \mathrm{ppm}$. The C-1 of $\gamma_{1}$ appeared at $99.75 \mathrm{ppm}$ as a shoulder on the peak of the $C^{\prime \prime}-1$ signal, its integration could only be approximated to be $18 \%$ of $C^{\prime \prime}-1$. The $C-1$ of $\gamma_{2}$ had a chemical shift of $104.72 \mathrm{ppm}$. The enrichment in the $\gamma$ spectrum was found to be $\mathrm{C}^{\prime \prime}-16.8$, $C^{\prime}-17.6$ and C-1 6.6, a total of 21.0-fold enrichment (Table 5).

Although there were small differences between the extent of enrichment of the three anomeric carbons, the result can be interpreted, within experimental error, as indicating that these three monosaccharide moieties were efficiently and nearly equally enriched by $\left[{ }^{13} \mathrm{C}\right]$ glucosamine. This unexpected 
Table 5. ${ }^{13} \mathrm{C}$ Enrichment in cinodine by D-[1- $\left.{ }^{13} \mathrm{C}\right]$ glucosamine incorporation.

\begin{tabular}{|c|c|c|c|c|c|c|}
\hline \multirow{2}{*}{$\begin{array}{l}\text { Carbon } \\
\text { position }\end{array}$} & \multicolumn{2}{|c|}{$\beta$} & \multicolumn{2}{|c|}{$\gamma\left(\gamma_{1}, \gamma_{2}\right)$} & \multicolumn{2}{|c|}{$\begin{array}{l}\text { Calculated }{ }^{13} \mathrm{C} \\
\text { enrichment }^{\mathrm{a}}\end{array}$} \\
\hline & $\begin{array}{c}\text { Chemical } \\
\text { shift (ppm) }\end{array}$ & $\begin{array}{c}{ }^{13} \mathrm{C} \\
\text { enrichment }\end{array}$ & $\begin{array}{c}\text { Chemical } \\
\text { shift (ppm) }\end{array}$ & $\begin{array}{c}{ }^{13} \mathrm{C} \\
\text { enrichment }\end{array}$ & 1 ring & 3 rings \\
\hline C-1 & 103.5 & 5.2 & $\begin{array}{r}99.75\left(\gamma_{1}\right) \\
104.72\left(\gamma_{2}\right)\end{array}$ & 6.6 & 12.3 & 4.1 \\
\hline$C^{\prime}-1$ & 83.66 & 6.4 & 83.74 & 7.6 & - & 4.1 \\
\hline$C^{\prime \prime}-1$ & 97.58 & 7.4 & 97.79 & 6.8 & - & 4.1 \\
\hline Total & & 19.0 & & 21.0 & 12.3 & 12.3 \\
\hline
\end{tabular}

a Based on observed $\mathrm{D}-\left[1-{ }^{14} \mathrm{C}\right]$ glucosamine incorporation efficiency of $21.2 \%$ in this experiment.

result not only indicated that all three moieties are derived from glucosamine directly, but also ruled out the possibility that the two pentose sugars (rings B and C) might come from the hexose by cleavage between $\mathrm{C}_{1}-\mathrm{C}_{2}$ as in the glucose pentose pathway. Based on the NMR result, it is more likely that the pentoses were made by oxidation of the $\mathrm{C}_{0}-\mathrm{OH}$ to carboxylic acid, followed by decarboxylation. Since all the three sugar moieties were nearly equally enriched, it suggests that either the assembly of the trisaccharide chain was completed before the pentoses were made or the pentose synthesis was extremely rapid and the trisaccharide assembly was done with very little time lapse in between so that minimal dilution resulted.

\section{Acknowledgments}

The authors would like to thank Mr. Frederick HeIM for assistance in obtaining the NMR spectra and Dr. BARRY BUCKLAND for valuable discussion on fermentation medium improvement.

\section{References}

1) Martin, J. H.: Antibiotic BM 123 and production thereof. US Patent 4,007,167, Feb. 8, 1977

2) Tresner, H. D.; J. H. Korshalla, A. A. Fantini, J. D. Korshalla, J. P. Kirby, J. J. Goodman, R. A. Kele, A. J. Shay \& D. B. Borders: Glycocinnamoylspermidines, a new class of antibiotics. I. Description and fermentation of the organism producing the LL-BM123 antibiotics. J. Antibiotics 31: 394 397, 1978

3) Martin, J. H.; M. P. Kunstmann, F. Barbatschi, M. Hertz, G. A. Ellestad, M. Dann, G. S. Redin, A. C. Dornbush \& N. A. Kuck: Glycocinnamoylspermidines, a new class of antibiotics. II. Isolation, physicochemical and biological properties of LL-BM123 $\beta, \gamma_{1}$ and $\gamma_{2}$. J. Antibiotics 31: 398 404, 1978

4) Gustafson, R. H. \& G. A. Kemp: Antibacterial agent BM $123 \gamma$, salts and alkyl derivatives thereof for the control of shipping fever in cattle. US Patent 4,170,645, Oct. 9, 1979

5) Ellestad, G. A.; D. B. Cosulich, R. W. Broschard, J. H. Martin, M. P. Kunstmann, G. O. Morton, J. E. LANCASter, W. Fulmor \& F. M. LOvell: Glycocinnamoylspermidines, a new class of antibiotics. 3. The structures of LL-BM123 $\beta, \gamma_{1}$ and $\gamma_{2}$. J. Am. Chem. Soc. 100: $2515 \sim 2524,1978$

6) WAlker, T. E. \& R. BARKER: Synthesis of 2-amino-2-deoxy-D-[1-13 C]glucose and 2-amino-2-deoxy-D$\left[1{ }^{13} \mathrm{C}\right]$ mannose. Carbohydr. Res. 64: 266 270, 1978 